\title{
Japan looks to sea for the extra acres and airports
}

\section{Tokyo}

JAPAN is expanding into the sea. Several multi-billion dollar projects to construct reclaimed islands off Japan's coast are on the drawing board and reclamation work for the new Kansai International Airport is already under way. This is a massive operation calling for the creation of a man-made island of more than $5 \mathrm{~km}^{2}$ in Osaka Bay and connected to the mainland by a $4-\mathrm{km}$ road and rail bridge. The airport is due to be completed in 1993 at a cost of Y1 million million ( $\$ 6,600$ million); a further Y2.5 million million will be spent on construction of railways, expressways, a residential area, parks, a water supply and a sewage system. Future plans call for the airport to be more than doubled in size to accommodate two additional runways.

The soft clay floor of the bay will pose problems for Japan's civil engineers. After ground improvement by sand compaction and drainage techniques, an 11$\mathrm{km}$ wall will be built around the site before infilling with about 200 million $\mathrm{m}^{3}$ of sand and soil derived from the mainland.

This is not the first or last man-made island of such a scale to be built by Japan. Port Island, of comparable size to the new airport, was completed off Kobe in 1981, and Rokko Island, its twin nearby, is nearing completion. Osaka plans to create two new islands in its harbour by dumping domestic and industrial garbage behind retaining walls. And Tokyo has the most ambitious plans of all - the National Land Agency has called for the reclamation of $17 \mathrm{~km}^{2}$ along the waterfront of Tokyo Bay by 1995 , and under a cooperative government-private venture a bridge and tunnel will span the $15 \mathrm{~km}$ of Tokyo Bay between Kawasaki and Chiba Prefecture via a couple of artificial islands. The price of mainland property has made this reclamation programme attractive.

When the national government recently asked Tokyo metropolitan government to construct a loop to link the city centre with the coastal redevelopment plan, officials were appalled to discover that a $1.35-\mathrm{km}$ section between Toranomon and Shimbashi, although costing only Y2,000 million to build, would entail spending Y430,000 million to cover land purchase for the $40-\mathrm{km}$ wide road, the equivalent of more than $\$ 2,000$ million per kilometre of highway.

Redevelopment itself only tends to worsen the situation: when Tokyo announced plans to move the metropolitan government offices from the centre of town to a new site in Shinjuku on the outskirts, land prices in urban areas within 30 minutes' commuting distance of Shinjuku doubled in a few years to well over a million yen $(\$ 6,600)$ per $\mathrm{m}^{2}$.

Land prices are not the only problem. Many old city areas lack the necessary infrastructure, roads and sewage systems, for redevelopment; Osaka may boast a bullet train, but it still has open sewers that overflow during the rainy season.

So offshore development has proved attractive. There new land can be created for as little as $\mathrm{Y} 100,000$ per $\mathrm{m}^{2}$. The only objections come from local fishermen, who can usually be bought off with suitable compensation - for the new Kansai airport more than $\mathrm{Y} 40,000$ million was paid in compensation to the 3,400 fisher-

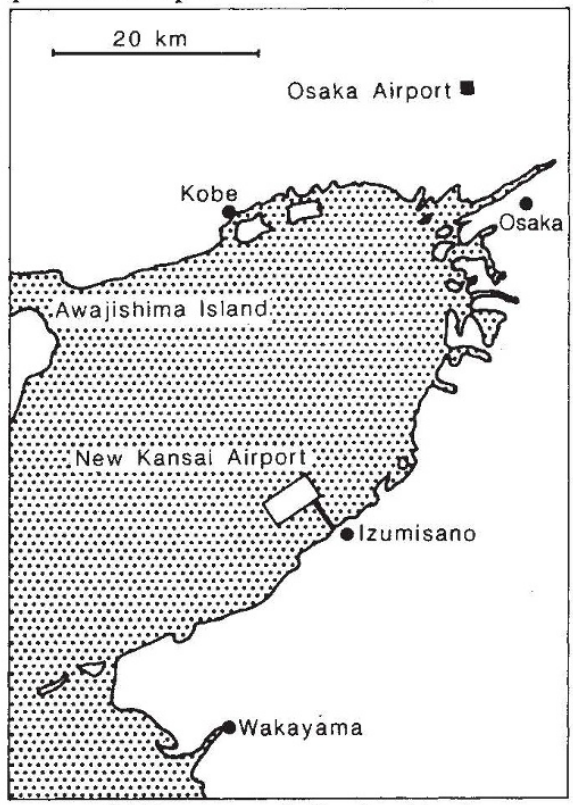

man of Hyogo and Osaka Prefectures. Few of these fisherman ever fish anywhere near the site, but in Japan a blanket approach to compensation is favoured to quell dissent among those most affected.

The new reclamation projects are joint government-industry ventures set up under a new law introduced last year to encourage private investment in public works. Main contractors are chosen under a designated bidder system, which means only select companies can bid for the project. Fifty per cent of the funding for the project is provided by the companies themselves, which buy low interest bonds from the local government.

The prospects for any foreign companies with plans to compete with local constructors seem slim. But following intense diplomatic efforts, the United States has managed to pick up at least one crumb from the Kansai airport contract. Bechtel Civil Corporation, a San Francisco-based engineering consulting firm, has won a Y30 million subcontract to survey facilities at international airports overseas.

\section{Export licence rules to ease?}

\section{Washington}

IN response to the publication of a National Academy of Science report critical of US export control policy, the Department of Commerce is proposing significant changes in its export licensing procedures. The aim is to stop "the growing shift away from American products" without jeopardizing national security.

Secretary of Commerce Malcolm Baldrige announced the proposed changes last week. Although some need further approval, either from the White House or from Congress, others will go into effect immediately. This week, for example, the department is expected to publish in the Federal Register its revised plans for the general certified end user (G-CEU) licence. Dubbed the "gold card" scheme when it was first suggested last summer (see Nature 323,$100 ; 1986$ ), it provoked strong criticism from industry and has been substantially revised as a result. Now, G-CEUs will be awarded to companies, such as Fiat in Italy, controlled by CoCom (Coordinating Committee on Export Controls) governments. A second general licence would allow routine shipments to all agencies of CoCom governments. Future efforts will extend G-CEUs to other Western companies.

Another change expected to be welcomed by industry will be a loosening of the socalled parts and components regulations. At present, anything manufactured outside the United States containing controlled US parts still requires a US export licence if re-exported. The new regulations will require licences for products containing some fraction (rumoured to be 20 per cent) of US parts or components.

Boyd McKelvain, head of the Industry Coalition on Technology Transfer, says the Commerce Department's plans are a "tremendous step in the right direction". He says the plans to eliminate many controls on low technology items could have a large impact on trade. McKelvain says the large US trade deficit coupled with the National Academy of Science's report allowed industry's voice to be heard.

But the Department of Defense has not been overwhelmingly enthusiastic about the Commerce Department's proposals, even though the G-CEU scheme came originally from Deputy Undersecretary of Defense, Stephen Bryen. There is still concern that tough controls are needed to prevent the Soviet Union from gaining access to sensitive US technology. The Defense Department is preparing its own agenda for revising export controls, said a Pentagon spokesman. Ultimately, the National Security Council will have to balance the concerns. 